\title{
In-vitro Evaluation of Botanicals against Rhizoctonia solani causing Root Rot in Soybean
}

\author{
Meeti Gupta ${ }^{1}, \operatorname{Ramkumar}$ Meena $^{1 *}$, Gopala $^{2}$ and Reeti Singh ${ }^{1}$ \\ ${ }^{1}$ Department of Plant Pathology, R.V.S. K. V. V, College of Agriculture, \\ Gwalior-472001, India \\ ${ }^{2}$ Department of Plant Pathology, R.V. S. K. V. V, College of Agriculture, Indore-452001, India \\ *Corresponding author
}

Keywords

Botanicals,

Rhizoctonia solani,

Root rot,

Soybean

\section{Article Info}

Accepted:

10 September 2019

Available Online:

10 October 2019

\section{A B S T R A C T}

Soybean [Glycine $\max (\mathrm{L}$.$) Merrill] is an important cash crop in India. It is considered as$ one of the main oil crop over the world. The state of Madhya Pradesh has been declared as "soybean state". The root rot caused by Rhizoctonia solani, most pathogenic fungi of soybean crop it attack on root of plant and destroy the proper functioning of the plant to take water (xylem vessels) and other nutrients upward (phloem vessels). The studies were carried out on Department of Plant Pathology, College of Agriculture, RVSKVV, Gwalior. The seven different plants parts viz., Allium sativum, Parthenium hysterophorus, Ocimum sanctum, Curcuma longa, Tagetes erecta, Azadira chtaindica and Eucalyptus boliqua were used in the investigation for controlling $R$. solani under in-vitro studied. Minimum mycelium growth of $R$. solani was recorded in A. sativum followed by P. hysterophorus, $O$. sanctum, C. longa, T. erecta, A. chtaindica and E. boliqua. Statistically, E. boliqua and $A$. indica were found at par with each other and statically significant at $(\mathrm{p}=0.05)$ with all other treatments. All tested botanicals significantly reduced the mycelial growth over the control except $A$. sativum and $P$. hysterophorus. Among the botanicals, minimum mycelial growth was recorded in $O$. basalicum followed by $C$. longa, $T$. erecta, A. indica, Eucalyptus boliqua. Statistically, A. sativum and P. hysterophorus were found at par with each other.

\section{Introduction}

Soybean [Glycine max (L.) Merrill] is the miracle crop of $21^{\text {st }}$ century. It is a major oil seed legume crop with high quality protein (40 to $42 \%$ ) and oil $20 \%$ employed to a variety of uses. The state of Madhya Pradesh has been declared as "soybean state". It occupies third place among the nine oil seed crops of India.
Soybean plants like many others legumes are capable of fixing and utilizing atmospheric nitrogen through symbiotic relationship with Rhizobium bacteria at the root of the crops. The crop thus improve soil fertility and economizes crop production not only for themselves but also for the next crops grown in rotation especially cereal crops (Nassiuma and Wasike, 2002). 
Soybean is subjected to many diseases caused by fungi, bacteria, virus and nematodes (Sweets, 2008). Among all these pathogens the root rot pathogenic fungi are major threat for this crop as these fungi attack on the root of the plant and destroy the proper functioning of the plant to take water and other nutrients upward. Fusarium spp., Rhizoctonia solani and Pythium spp. are considered as major soybean seedling pathogens, which contribute to stand reduction (Inam-Ul-Haq et al., 2012).

Now a day's fungicides in plant protection are widely used because fungicides help to reduce disease incidence and thus, boost up the crop yield that meets the hunger of exploded population. However fungicides are not a long term solution to maintain crop health. Applications of the synthetic chemicals have many ill effects on ecosystem. Besides, their non targeted effects and hazardous nature, petroleum based fungicides are not referred effectiveness because of development of resistant strains of pathogens. In the context, use of plant extract, to control plant disease is fully justified. During past several years, some noticeable success of disease control was achieved by using plant product, as they are economical and eco-friendly (Nene and Thaplial 1993). Root rot has become an important disease of soybean in recent past. Hence, a detailed and systematic study is required to manage this important disease.

\section{Materials and Methods}

The different plants parts were collected from R.V.S.K.V.V Farm and nursery. Different plant parts from seven plant viz. Allium sativum, Parthenium hysterophorus, Ocimum sanctum, Curcuma longa, Tagetes erecta, Azadira chtaindica and Eucalyptus boliqua were used in the investigation (Table 1). The fresh leaves rhizome and clove $(100 \mathrm{~g})$ of respective botanicals were washed, dried, weighted and brought in the laboratory for the reparation of boiled extract. The leaves/rhizome/clove were incorporated with water on weight/volume basis then boiled for half an hour and filtered. The extract was stored in refrigerator and used for bioassay of test fungus.

The potato dextrose agar (PDA) medium was prepared. The extract is filtered through sterilized seeds filter and added in sterilized medium at nearly $60^{\circ} \mathrm{C}$ after cooling of sterilized PDA the medium was poured in 3 sterilized petri-plates. After solidification these plates were inoculated at the center with $7 \mathrm{~mm}$ fungal disc from 7 days old culture of $R$. solani control (without plant extract) was maintained for comparison. These plates were incubated at $28 \pm 2^{0} \mathrm{C}$ (Grover and Moore, 1962). All the treated and control Petri dishes were incubated at $28 \pm 2^{\circ} \mathrm{C}$ in B.O.D. incubator. After incubation for 3,5 , and 7 days the diameter of fungal colony was measured in $\mathrm{mm}$ in each treatment. The efficacy of plant extracts was determined against growth of pathogen in control plates.

\section{Results and Discussion}

In the present study seven botanicals viz. Ocimum sanctum leaf, Azadirachta indica leaf, Parthenium hysterophorus leaf, Tagetes erecta leaf, Curcuma longa rhizome, Eucalyptus boliqua leaf and Allium sativum clove were evaluated 3,5 and 7 days intervals against $R$. solani under in-vitro condition (Table 1).

All the plant extracts significantly controlled the mycelium growth of $R$. solani on PDA. Minimum growth of $R$. solani were recorded in Allium sativum $(5.80 \mathrm{~mm})$ at 3 days after inoculation followed by Parthenium hysterophorus leaf $(8.08 \mathrm{~mm})$, Ocimum sanctum leaf $(10.00 \mathrm{~mm})$, Curcuma longa rhizome $(10.63 \mathrm{~mm})$, Tagetes erecta leaf (12.00 $\mathrm{mm})$, Azadirachta indica leaf (12.75 
$\mathrm{mm})$, Eucalyptus boliqua leaf (14.25 $\mathrm{mm})$ and Control (23.25 mm) (Table 2, Plate 1 and Fig. 1). Statistically, Eucalyptus boliqua leaf and Azadirachta indica leaf were found at par with each other at 3 days after inoculation.

At 5 days after inoculation, all tested botanicals significantly reduced mycelial colony diameter over the control. Among the botanicals, minimum mycelial growth was recorded in Allium sativum clove $(7.40 \mathrm{~mm})$ and Parthenium hysterophorus leaf (9.00 $\mathrm{mm})$. Ocimum bacilicum leaf $(12.00 \mathrm{~mm})$ followed by Curcuma longa rhizome (21.50 $\mathrm{mm})$, Tagetes erecta leaf $(23.63 \mathrm{~mm})$, Azadirachta indica leaf $(24.75 \mathrm{~mm})$, Eucalyptus boliqua leaf $(31.00 \mathrm{~mm})$, and Control $(47.50 \mathrm{~mm})$. Statistically, Allium sativum clove and Parthenium hysterophorus leaf were found at par with each other at 5 days after inoculation (Table 2, Plate 1 and Fig. 1).

Per cent inhibition of mycelial growth were recorded after seven days of inoculation, all tested botanicals significantly reduced mycelial colony diameter over the control. Among the botanicals, minimum mycelial growth were recorded in Allium sativum clove $(13.58 \mathrm{~mm})$ followed by Parthenium hysterophorus leaf (15.08 $\mathrm{mm})$, Ocimum sanctum leaf (31.00 $\mathrm{mm})$, Curcuma longa $(35.00 \mathrm{~mm})$, Tagetes erecta $(36.13 \mathrm{~mm})$, Azadirachta indica leaf $(37.13 \mathrm{~mm})$, Eucalyptus boliqua $(40.88 \mathrm{~mm})$ and Control (66.25 mm).

Table.1 Different plant products used for experimental purpose against $R$. solani

\begin{tabular}{|c|c|c|c|c|c|}
\hline S. No. & Scientific name & $\begin{array}{c}\text { Common } \\
\text { name }\end{array}$ & Family & $\begin{array}{c}\text { Use of } \\
\text { plant part }\end{array}$ & $\begin{array}{c}\text { Conc. } \\
(\mathbf{\%})\end{array}$ \\
\hline $\mathbf{1}$ & Ocimum sanctum & Tulsi & Lamiaceae & Leaves & 20 \\
\hline $\mathbf{2}$ & Azadira chtaindicaL. & Neem & Meliaceae & Leaves & 20 \\
\hline $\mathbf{3}$ & Parthenium hysterophorusL. & Gajarghas & Asteraceae & Leaves & 20 \\
\hline $\mathbf{4}$ & Tagete serecta & Marigold & Compositae & Leaves & 20 \\
\hline $\mathbf{5}$ & Curcuma longa & Haldi & Zingiberaceae & Rhizome & 20 \\
\hline $\mathbf{6}$ & Eucalyptus boliqua & Nilgiri & Myrtaceae & Leaves & 20 \\
\hline $\mathbf{7}$ & Allium sativum L. & Garlic & Amaryllidaceae & Cloves & 20 \\
\hline
\end{tabular}

Table.2 Effect of different botanicals and plant extracts on the growth of $R$. solani

\begin{tabular}{|c|l|c|c|c|}
\hline \multirow{2}{*}{ S.No. } & \multicolumn{3}{|c|}{ Treatments } & \multicolumn{3}{c|}{ Mycelial growth (mm) at } \\
\cline { 3 - 5 } & & $\mathbf{3}$ days & $\mathbf{5}$ days & $\mathbf{7}$ days \\
\hline $\mathbf{1}$ & Ocimum sanctum & 10.00 & 12.00 & 31.00 \\
\hline $\mathbf{2}$ & Azadirachta indica & 12.75 & 24.75 & 37.13 \\
\hline $\mathbf{3}$ & Parthenium hysterophorus & 8.08 & 9.00 & 15.08 \\
\hline $\mathbf{4}$ & Tagetes erecta & 12.00 & 23.63 & 36.13 \\
\hline $\mathbf{5}$ & Curcuma longa & 10.63 & 21.50 & 35.00 \\
\hline $\mathbf{6}$ & Eucalyptus boliqua & 14.25 & 31.00 & 40.88 \\
\hline $\mathbf{7}$ & Allium sativum & 5.80 & 7.40 & 13.58 \\
\hline $\mathbf{8}$ & Control & 23.25 & 47.50 & 66.25 \\
\hline & SE(m) \pm & $\mathbf{0 . 7 0}$ & $\mathbf{1 . 0 5}$ & $\mathbf{1 . 0 2}$ \\
& CD at 5 \% & $\mathbf{2 . 0 6}$ & $\mathbf{3 . 1 0}$ & $\mathbf{2 . 9 8}$ \\
\hline
\end{tabular}



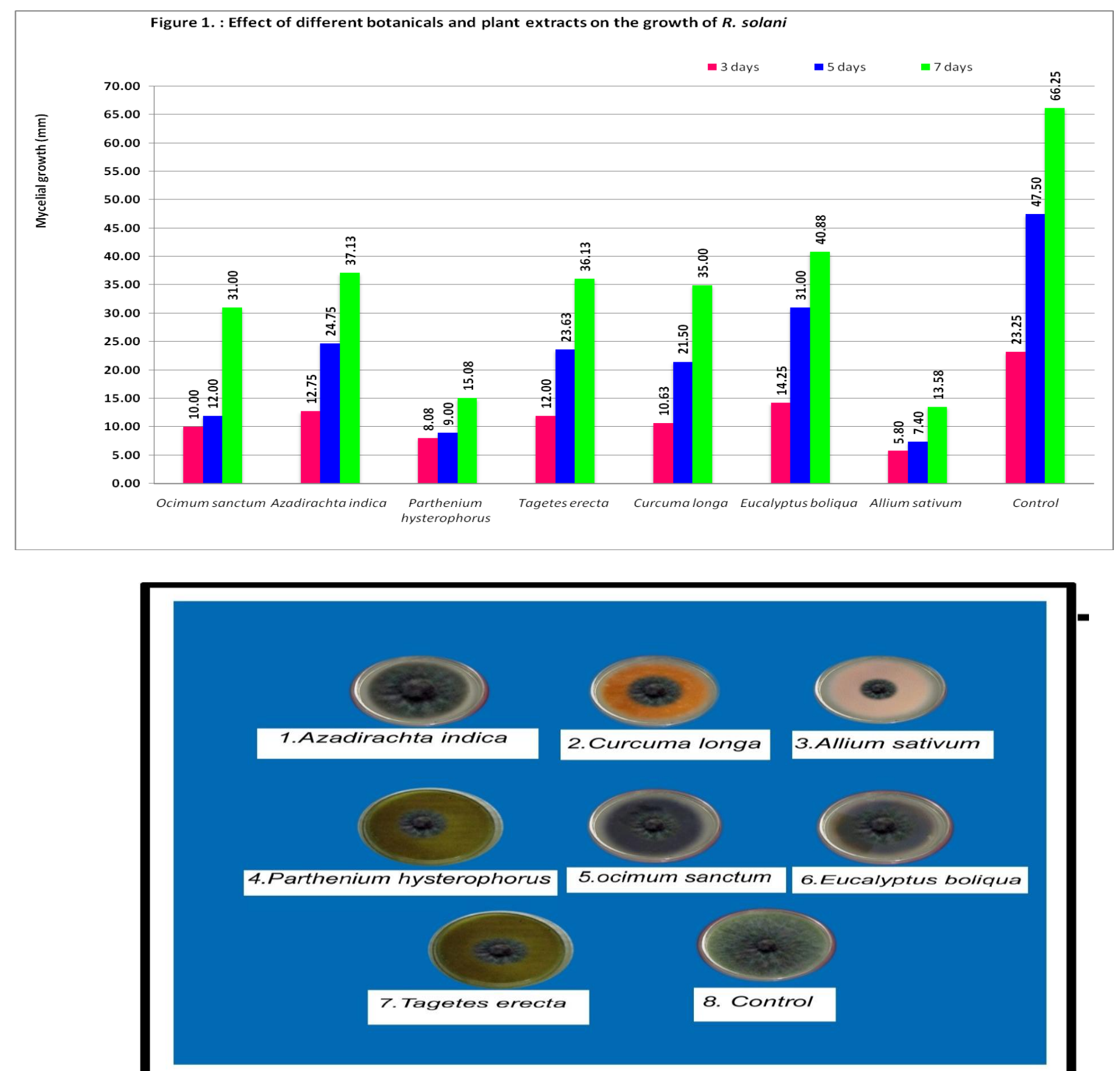

Plate $1 / n$-vitro evaluation of botanicals aganist Rhizoctonia solani

Statistically, A. sativum and $P$. hysterophorus were found at par with each other at 7 days after inoculation (Table 2, Plate 1 and Fig. 1).

As agricultural production intensified over the past few decades, growers became more and more dependent on agrochemicals as a reliable method of crop protection. However increased use of chemicals caused several negative effects for example development of pathogen resistance to applied chemicals and their non-target environmental impacts. Moreover increasing cost of pesticides, particularly in developing countries and 
search for pesticide free food in developed countries has led to a search for substitutes for these products. Moreover there are many diseases in which chemical solutions are ineffective.

The use of organic matter in the soil is an old practice considered essential for sustaining the thriftiness and productivity of crop. In addition to providing necessary nutrient elements, organic matter also influences soil physical characters such as pore size, aeration, temperature, water retention capacities etc. These help in better solubilization of minerals which together with the nutrients released by decomposing matter help in rapid extension of the root system, better uptake of nutrients, retention of added nitrogen for a longer period and finally better plant vigor even if the disease has not been significantly checked (Singh, 1983). Neem plant (Azadirachta indica) possesses biologically active compounds, mainly alkaloids such as isoprenoids that control various pests including fungi (Anwar-ul-Haq, 1993). In this experiment result was found as the lowest mycelial growth of $R$. solani was recorded in clove extract of garlic (Allium sativum L.) which was found significantly superior among all the treatment with lowest mycelial growth of pathogen $(25.33 \mathrm{~mm})$ (Sharma et al., 2018).

\section{References}

Anwar-Ul-Haq, M. (1993). Effect of neem and neem products on the in-vitro survival of Macrophomina phaseolina and Charcol rot of mungbean. M.Sc.
Thesis, Department of Plant Pathology, University of Agriculture, Faisalabad, Pakistan.

Grover, R.K. and Moore J.D. (1962). Toxicometric studies of fungicides against brown rot organisms Sclerotinia fructicola and S. laxa. Phytopathol., 52: 876-880.

Inam-Ul-Haq, M.; MehmoodSajid, Rehman; Hafiz, Mujeebur Ali, Zahid and Tahir, M.J. (2012).Incidence of root rot diseases of soybean in Multan Pakistan and its management by the use of plant growth promoting Rhizobacteria. Pakistan J. Bot., 44 (6): 2077-2080.

Nassiuma, D. and Wasike, W. (2002). Stability assessment of soybean varieties in Kenya.African Crop. Sci. J., 10 (2): 139-144.

Nene, Y.L. and Thapliyal, P.N. (1993). Fungicides in Plant Disease Control. Third edition. Oxford and IBH Publishing Co. New Delhi, pp, 531.

Sharma, Kishan Kumar, Patil, Vijay A., Sharma, Jitendar Kumar and Kulmitra, Akhilesh Kumar (2018). In vitro Evaluation of Botanicals against $R$. solani Causing Sheath Blight of Paddy. Int. J. Curr. Microbiol. App. Sci Special Issue-7: 3316-3322.

Singh, R.S. (1983). Organic amendments for root disease control through management for soil microbiota and the host. $5^{\text {th }}$ Annual Conf. Soc. Univ. Agric. Sci., Bangalore. India.

Sweets, L. (2008). Early season soybean diseases. Integrated Pest Crop Manage., 18 (12): 82.

\section{How to cite this article:}

Meeti Gupta, Ramkumar Meena, Gopala and Reeti Singh. 2019. In-vitro Evaluation of Botanicals against Rhizoctonia solani causing Root Rot in Soybean. Int.J.Curr.Microbiol.App.Sci. 8(10): 1205-1209. doi: https://doi.org/10.20546/ijcmas.2019.810.141 